\title{
Decreased Bone Tissue
}

National Cancer Institute

\section{Source}

National Cancer Institute. Decreased Bone Tissue. NCI Thesaurus. Code C139139.

A decrease in the amount of bone tissue as compared to a standard or norm. 